\title{
A NEW SOUTHWESTERN SPECIES OF
}

\section{$M A L L O T A$ MEIGEN (DIPTERA : SYRPHIDAE) ${ }^{1}$}

\section{By Frank Montgomery Hull \\ University of Mississippi}

I wish to thank Dr. Darlington and Dr. Bequaert for the opportunity to study the Syrphid material of the Museum of Comparative Zoology. This new species is in the Museum collections.

Mallota bequaerti, n. sp.

A large species characterized by dense yellow pile on mesonotum and scutellum. The abdomen is entirely short, densely black setate, with the exception of the fourth segment which is short, golden red, appressed setate. This species is very distinct from other forms, including facialis Hunter, var. flavoterminata Jones, because of the presence of the large, distinct, subquadrate, dark brown spots on the middle of the wing and the presence of the rather widely separated eyes of the male. Length, about $16 \mathrm{~mm}$.

Male. Head: eyes bare, the vertex is convex and shining black with black pile; the ocelli lie in an equilateral triangle. The lateral margins of the vertical triangle, anterior and lateral to the ocelli, are striate. The eyes are separated by a distance at least equal to the space between the posterior ocelli. The front is shining black broadly down the middle and in front of the antennae, with the sides rather thickly dusted with pale yellowish pollen, which becomes more brownish medially; this leaves approximately the middle two-thirds of the front shining and bare, with the ground color black. The face is black, with a broad, shining, bare, medial stripe, its sides widely, silvery white micropubescent; pile of the face and front

${ }^{1}$ Published with a grant from the Museum of Comparative Zoology at Harvard College. 
white. In profile the face is distinctly concave above the low tubercle; the cheeks are shining black. The first two segments of the antennae are black; the third segment distinctly wider than long and evenly rounded apically, a uniformly dark reddish brown color; the arista thickened, bare and entirely light brownish-yellow. Occiput black, densely covered with silvery pollen along the middle and below; this pollen begins near the upper third of the eye; the pile of the occiput is yellowish throughout, including long, dense, yellow pile immediately behind the vertex.

Thorax: the mesonotum is black, but is densely covered with light ochreous yellow pollen and thick, long, dense opaque, yellow pile, including the humeri and throughout the entire dorsum. The scutellum is subtranslucent ochreous yellow and covered with the same sulfur yellow pile; pleura black with thick, opaque yellow pile on upper portion of the mesopleura, which becomes sparse and scattered and less conspicuous on the ventral portion of the mesopleura and on the anterior and upper portion of the sternopleura. The pile on the posterior corner of the sternopleura and all of the pile of the pteropleura is black. Squamae subtranslucent brownish white; fringe brownish yellow; halteres yellow with dark brown knob.

Legs: all of the femora black or nearly so; in some lights the hind femora, towards the base, appear to be dark reddish sepia; the anterior and middle tibiae are nearly black, becoming more faintly dark brown near the base and apex; hind tibiae similarly colored, markedly flattened apically and distinctly arcuate. The pile of the femora and of the tibiae black, except along the anterior surface of the anterior tibiae, where the pile is yellow and there are a few yellow hairs along its posterior surface. All of the tarsi brown with black pile dorsally.

Wings: hyaline, with a strong, rather distinctly delimited, large, subquadrate, sepia brown cloud situated in the middle of the wing; this spot encloses and covers the anterior margin, the whole basal half of the first posterior cell; the apical half of the first basal cell; the upper basal corner of the third posterior cell; the apex of the second 
basal cell and narrowly the posterior margin of the second basal cell. The costal cell is entirely pale brown, becoming darker towards the apex.

Abdomen: of the usual shape, except that it is perhaps somewhat more tapered posteriorly; it is quite broad basally and distinctly wider than the thorax and begins to rapidly narrow from the base of the second segment so that the shape is that of a short wedge-shaped triangle. The first, second and third segments are black or nearly so; in some lights close scrutiny suggests that the second segment and the third segment have a slight appearance of dark reddish sepia, which is almost black in color. The fourth segment is blackish basally, but becomes very dark mahogany reddish posteriorly; this is especially apparent when this segment is viewed from the rear; actually the fourth segment is also very dark and might be called black. The pile of the abdomen is dense, short, subappressed and black, but longer on the sides of the first and second segments; on the fourth segment it is appressed, short, abundant and golden reddish in color. The lateral pile along the extreme margin of the third segment is also golden. Hypopygium dark reddish brown with golden pile.

Holotype: male, Chisos Mts., Big Bend National Park, Texas; collected by J. Bequaert. I take pleasure in naming this handsome species in honor of its collector. 

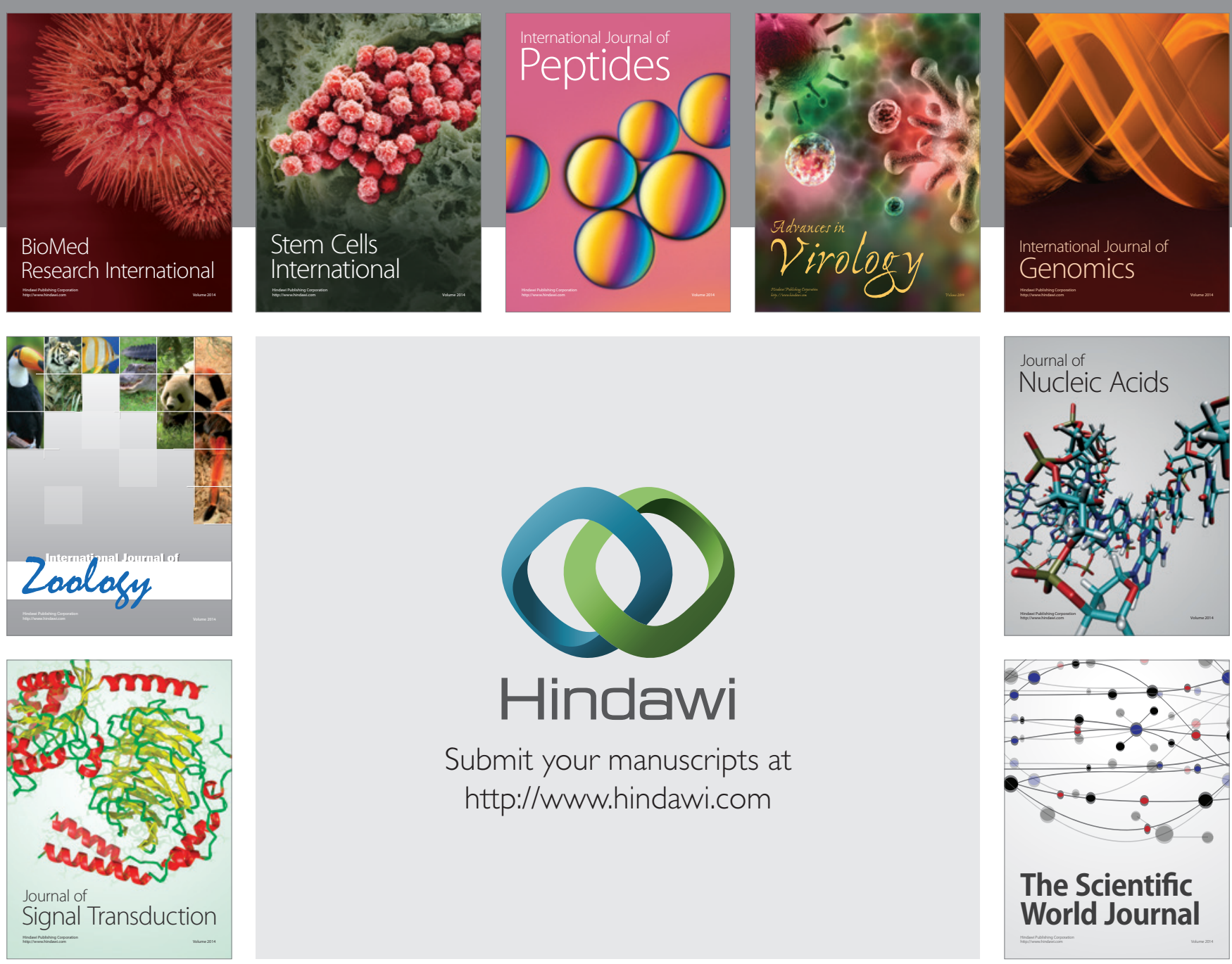

Submit your manuscripts at

http://www.hindawi.com
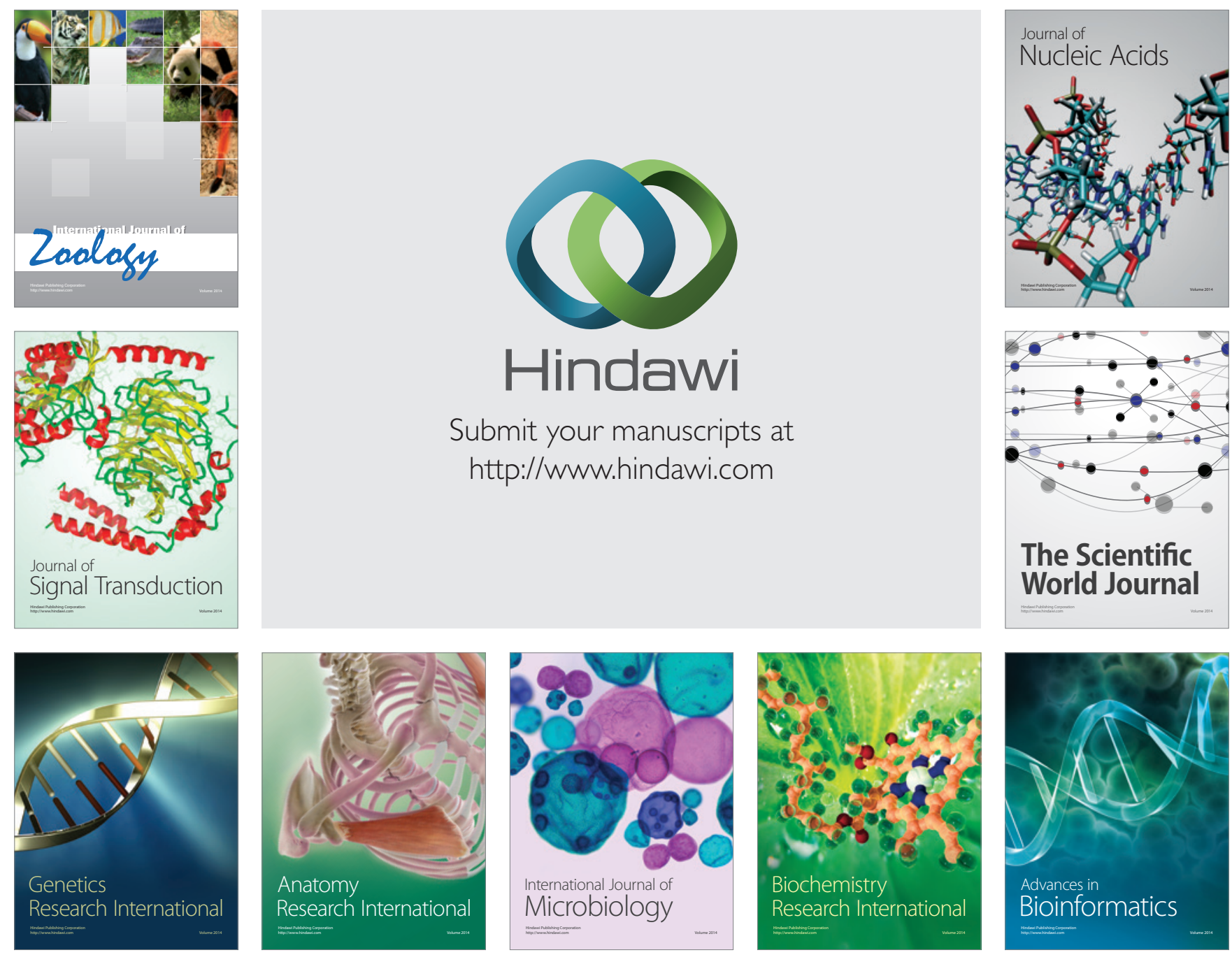

The Scientific World Journal
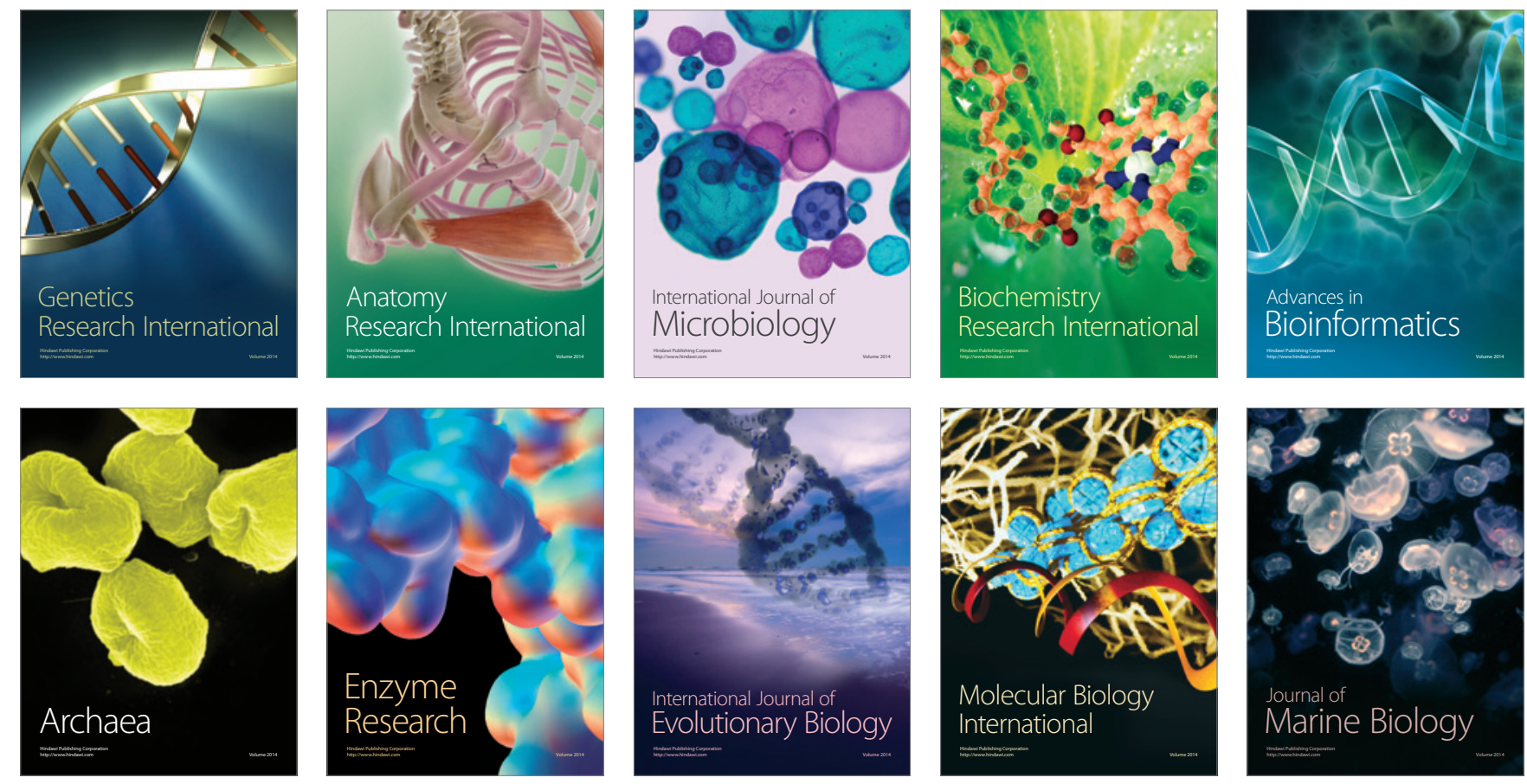